
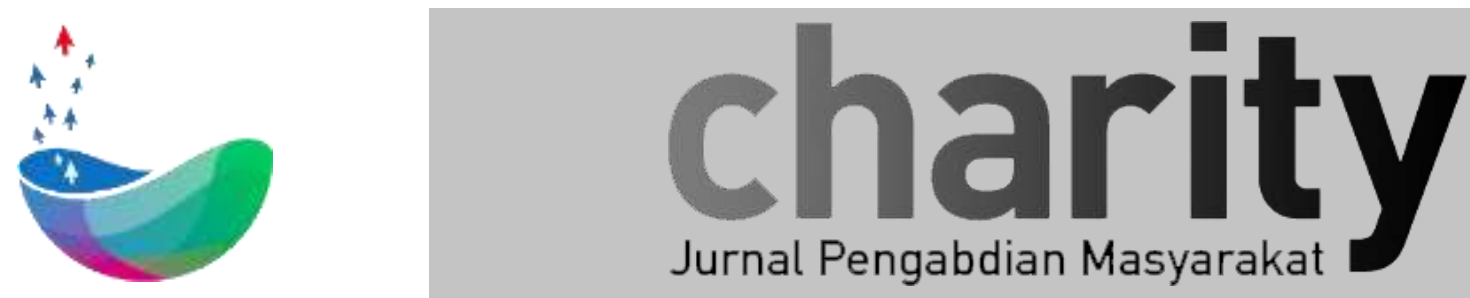

\title{
PENINGKATKAN PENDAPATAN BDC ( BUSINESS DEVELOPMENT CENTRE) DI PANGANDARAN MELALUI INFORMASI PENGGUNAAN E-COMMERCE
}

\author{
Rahmat Hidayat ${ }^{1}$. Ati Mustikasari ${ }^{2}$, Arry ${ }^{3}$ Dicky ${ }^{4}$, Sri Widaningsih ${ }^{5}$ Leni Cahyani ${ }^{6}$ \\ Program Studi Manajemen Pemasaran, Fakultas Ilmu Terepan, Universitas Telkom \\ Program Studi Desain Komunikasi Visual, Fakultas indrustri kreatif, Universitas Telkom \\ Program Studi Desain Komunikasi Visual, Fakultas indrustri kreatif, Universitas Telkom \\ rahmathidayat@tass.telkomuniversity.ac.id
}

\section{INFO ARTIKEL}

Diterima 4 Juli 2019

Direvisi 11 Juli 2019

Disetujui 30 Agustus 2019

Tersedia Online 9 September 2019

\begin{abstract}
ABSTRAK
Upaya menyiapakan pengelolaan BDC yang menghadirkan kontribusi sognifikan dari pelaku usaha produktif melalui KSM, kegiatan penguatan kapasitas atau pelatihan merupakan kegiatan yang sangat penting dan strategis delam kegiatan pilot BDC. Segala uapaya yang telah dicoba dan dikerahka, akan tetapi masih banyak hal yang masih belum bisa dilakukan secara optimal sebagai contohnya adalah proses pemasaran yang masih terhamba. Rendahnya networking yang dimiliki sehingga perbandingan antara penjualan yang dilakuka belum mampu menutupi biaya oprasional gaji. Rendahnya penjualan dikarnakan minimnya pengetahuan terhadap bisnis E-commerce menjadi hambatan paling besar dalam tubuh BDC. Belum lagi pemberian bran dan konsep packaging yang masih teramat standar dam belum memenuhi syarat sebuah merek atau packaging yang bagus. Dengan adanya kegiatan PKM(Pengabdian Kepada Masayarakat) diharapakan UKM yang bernaung di BDC semakin paham tentang bagaimana caranya megoptimalisasi penjualan melalui media online (e-commerce). Selain itu juga diharapkan bisa membuat merek baru sesuai kebutuhan pasar.
\end{abstract}

Keyword :BDC

Korespondensi :

Direktorat Penelitian dan Pengabdian Masyarakat, Universitas Telkom

Jl. Telekomunikasi No. 1, Terusan Buah Batu, Bandung, 40257

Indonesia.

E-mail: charity@telkomuniversity.ac.id

ORCID ID: 0000-0003-1937-7767

Penulis Pertama: Rahmat Hidayat https://doi.org/ 10.25124/charity.v2i2.2106

Paper_reg_number 2106 (C) The Authors. Published by Directorate of Research and Community Service, Telkom University.

This is an open access article under the CC BY-NC 4.0 license (https://creativecommons.org/licenses/by-nc/4.0/) 


\section{PENDAHULUAN}

Pangandaran adalah satu daerah pesisir pantai di Indonesia yang bisa disebut memiliki ragam kekayaan alam. Selain wisata pantai yang indah, hasil laut garapan nelayan setempat juga melimpah, ditambah pepohonan kelapa yang menghasilkan buah kelapa berkualitas. Namun sayang, sebagian warga wilayah pemekaran dari Kabupaten Ciamis, Tasikmalaya, Provinsi Jawa Barat itu masih tergolong kategori masyarakat berpenghasilan rendah (MBR). Mayoritas masyarakat Kabupaten Pangandaran memang berprofesi sebagai nelayan dan pengelola wisata. Mereka juga mengembangkan potensi hasil laut seperti ikan, kepiting, udang menjadi aneka olahan penganan. Sementara selain dijual langsung ke para wisatawan yang berkunjung ke Pantai Pangandaran sebagai minuman kelapa muda, hasil kelapa lainnya juga diolah sebagai bahan bumbu masakan. Kondisi itu menginspirasi Program Kota Tanpa Kumuh (Kotaku) Kementerian Pekerjaan Umum dan Perumahan Rakyat (PUPR) untuk membuat program Business Development Center (BDC) atau pusat pengembangan usaha di Pangandaran pada 2015. BDC Pangandaran dibentuk berdasarkan Surat Keputusan Bupati Nomor 602 / KPTS 389 - HUK. ORG / 2015 tanggal 5 November 2015. Pascapembentukan, disusunlah komite dan pengelola BDC dari hasil forum musyawarah kota yang terdiri dari unsur badan keswadayaan masyarakat (BKM), perwakilan KSM, organisasi perangkat daerah (OPD), perguruan tinggi, dan berbagai unsur kewilayahan lainnya (sumber : www.kadinpangandaran.or.id).

BDC atau Business Development Center Kabupaten Pangandaran adalah sebuah lembaga nirlaba yang ditunjuk oleh pemerintah dalam hal ini Kementrian Pekerjaan umum untuk membantu meningkatkan dayabeli masyarakat dengan berbagai kegiatan inkubasi UKM dan Industri kecil

Pengelolaan BDC yang menghadirkan kontribusi signifikan dari pelaku usaha produktif melalui KSM (Kelompok Swadaya Masyarakat), kegiatan penguatan kapasitas atau pelatihan merupakan kegiatan yang sangat penting dan strategis dalam kegiatan Pilot BDC. Penguatan kapasitas ini dilakukan baik di level konsultan yang terdiri dari Tenaga Ahli OC dan Korkot (sebagai pendamping BDC) maupun di level BDC yang terdiri dari Komite dan Pengelola BDC.

Ada Gula ada Semut, pepatah itu sering kali anda mendengarnya, tapi bagaimana dengan Gula Semut? Mungkin anda baru mendengarnya. Gula semut adalah varian gula yang bahan dasarnya sama dengan gula merah, hanya saja melewati satu proses kembali untuk menjadi gula semut. Gula semut dikembangkan oleh BDC (Business Development Center) dengan membina masyarakat khususnya di Kecamatan Pangandaran Kabupaten Pangandaran, mulai dari cara memproduksi gula semut, pengemasan hingga pemasaran. Dikutip dari website BDC Pangandaran, Seiring meluasnya pasar dan meningkatnya keuntungan, makin banyak pula perajin gula yang bergabung dalam produksi gula semut. Dari awalnya hanya 54 orang, kini menembus 140 orang di Kecamatan Pangandaran. Kapasitas produksi pun sudah mencapai 8-10 ton per bulan. Saat ini, dari kapasitas produksi itu, rata-rata 3 ton di antaranya diperuntukkan bagi pasar Jepang dan Eropa, meski proses penjualannya masih melalui perantara eksportir gula di Purwokerto, Jawa Tengah, Rasanya khas, tak jau berbeda dengan manis gula merah, tapi lebih lembut. Dengan kadar air yang lebih rendah dan tidak boleh lebih dari $2 \%$ menjadikan gula semut tahan lama hingga 2 tahun. Saat ini BDC Pangandaran sebagai fasilitator masyarakat dalam mengembangan produk gula semut sedang berupaya untuk mendapatkan berbagai 
sertifikasi supaya gula semut yang dihasilkan lebih berkualitas dan memiliki nilai jual yang tinggi. (Sumber : news.mypangandaran.com)

\section{MASALAH}

Pembangunan usaha masyarakat pesisir memiliki persoalan mikro dan makro. Permasalahan mikro meliputi persoalan internal masyarakat daerah nelayan dan petani ikan, gula semut, kopi menyangkut aspek sosial budaya seperti pendidikan, mentalitas, dan sebagainya. Hal tersebut mempengaruhi sifat dan karakteristik masyarakat nelayan dan petani ikan. Permasalahan makro yaitu persoalan sosial yang menyangkut ketergantungan sosial. Karakter sebagian besar masyarakat pesisir pantai tergantung akan faktor-faktor sebagai berikut (laporan akhir Inv Pangandaran):

a. Kondisi lingkungan yang rentan pada kerusakan, pencemaran serta degradasi kualitas lingkungan.

b. Ketergantungan terhadap musim.

c. Ketergantungan kepada pasar yang merespon setiap produk yang ditawarkan harus segera dijual untuk memenuhi kebutuhan hidup sehari-hari atau membusuk sebelum laku dijual, belum lagu fluktuasi harga yang sangat berpengaruh terhadap kondisi sosial Nelayan.

\section{METODE KEGIATAN}

Metode Kegiatan Pengabdian yang digunakan dalam acara pengabdiaan masyarakat ini adalah dengan memberikan pelatihan/penyuluhan guna mengembangkan potensi yang dimiliki oleh mitra dan menjawab permasalahan dari solusi pengrajin yang ada di Kecamatan wonoharjo pangandaran terutama BDC.Teknik yang digunakan melalui wawancara kepada pemerintah desa dan para pengrajin didesa serta komunitas BDC pangandaran, sehingga informasi yang diberikan bisa memenuhi kebutuhan dan menyelesaikan permasalahan yang dihadapi para pengrajin.

\subsection{Teknik Pengumpulan Data}

Teknik Pengambilan data berupa pertanyaan dari survey, wawancara dan observasi.

Masyarakat sasaran pada program pengabdian masyarakat adalah pelaku usaha kecil . namun banyak hal yang masih terkendala dan perlu pengembangan inovasi diberbagai bidang yang mendukung proses kelancaran usaha yang di jalaninya.

A. Observasi

Observasi merupakan pengamatan yang dilakukan dalam rangka mendapatkan gambaran empirik dilokasi yang telah ditentukan dalam hal pertumbuhan terkini serta potensi yang di miliki oleh loksai tersebut.

B. Wawancara

Wawancara merupakan tatap muka yang dilakukan oleh tim dalam rangka mendapatkan data-data yang dibutuhkan terhadap para pelaku ekonomi yang terkait di lokasi yang menjadi target dalam hal ini adalah pangandaran. Para pelaku ekonomi yang terkait yang diwawancarai terutama pihak pemerintah, investor, pengusaha dan masyarakat umum. 


\section{Studi Dokumentasi}

Studi dokumentasi adalah sebuah proses pengumpulan data2 yang mendukung dalam pencapaian sebuah kegiatan baik data internal seperti data pemerintah (Pemprov Jabar) atau Pemkab JaBar atau data eksternal yang berasal dari luar pemerintahan serta data-data yang berasala dari buku atau literatur yang mendukung..

D. FGD atau Focus Group Discussion adalah kegiatan untuk mencari solusi dalam Rencana Kebutuhan Investasi Pusat Pertumbuhan di Pangandaran

\subsection{Teknik Analisis Data}

Deskriptif kuantitatif adalah teknik analisis data yang dilakukan yang bertujuan untuk mendap Para peserta pelatihan yang rata-rata para masyarakat yang membuat kerajinan, pengolahan produk dari kelapa, dimana bergerak dalam memproduksi piring lidi, batok kelapa peserta cukup antusias dalam mengikuti pelatihan, kemungkinan hal ini diharapkan bagi mereka dapat meningkatkan wawasan ataupun pengetahuan maupun kemampuannya dalam meningkatkan keterampilan dalam menggunakan media sosial ataupun pemahamannya dalam dunia internet. Hal ini terbukti dari adanya beberapa peserta yang mengajukan pertanyaan berkaitan dengan fasilitas perolehan bantuan modal maupun prosedur penggunaan media sosial dalam usaha meningkatkan produksi dan penjualannya, sehingga mereka berharap dapat memasarkan dan mempopulerkan produk secara lebih luas.atkan gambaran karakteristik penduduk dan kondisi perekonomian masyarakat.

\subsection{Lokasi, Waktu, dan Durasi Kegiatan}

Kegiatan akan dilaksanakan di balai pertemuan BDC pangandaran desa Sukahurip Kabupaten Pangandaran, Jawa Barat.

\section{ANALISA HASIL KEGIATAN}

\subsection{Kegiatan}

Berdasarkan hasil ke kelompok BDC pangandaran BDC atau Business Development Center Kabupaten Pangandaran adalah sebuah lembaga nirlaba yang ditunjuk oleh pemerintah dalam hal ini Kementrian Pekerjaan umum untuk membantu meningkatkan dayabeli masyarakat dengan berbagai kegiatan inkubasi UKM dan Industri kecil.

a. Meningkatkan penjualan produk BDC

b. Memperkenalkan produk unggulan kabupaten pangandaran

c. Memberikan Berpeluang mendapatkan pesanan produk lebih banyak.

d. Mempermudah melakukan transasksi dengan calon konsumen

e. Mendapatkan jaringan baru dari berbagai pihak untuk mengem- bangkan usaha kedua mitra.

f. Promosi untuk produk baru, akun efektif bagi mitra.

g. Performen usaha / Industri kedua mitra semakin meningkat.

h. mitra memiliki Pelanggan baru baik ritel besar dan ritel kecil di jawa barat lebih luas lagi ke pada luar negri penjualannya 


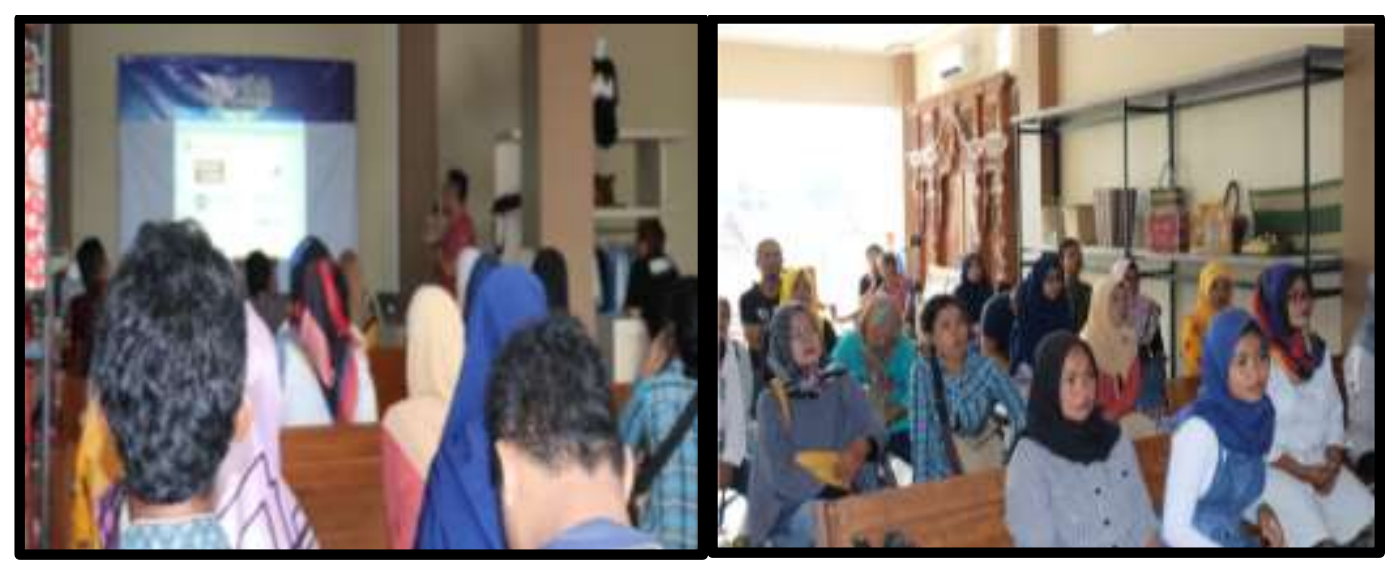

Gambar 3.1

Pelaksanaan Pemberian Materi Pembuatan Brand dan Design

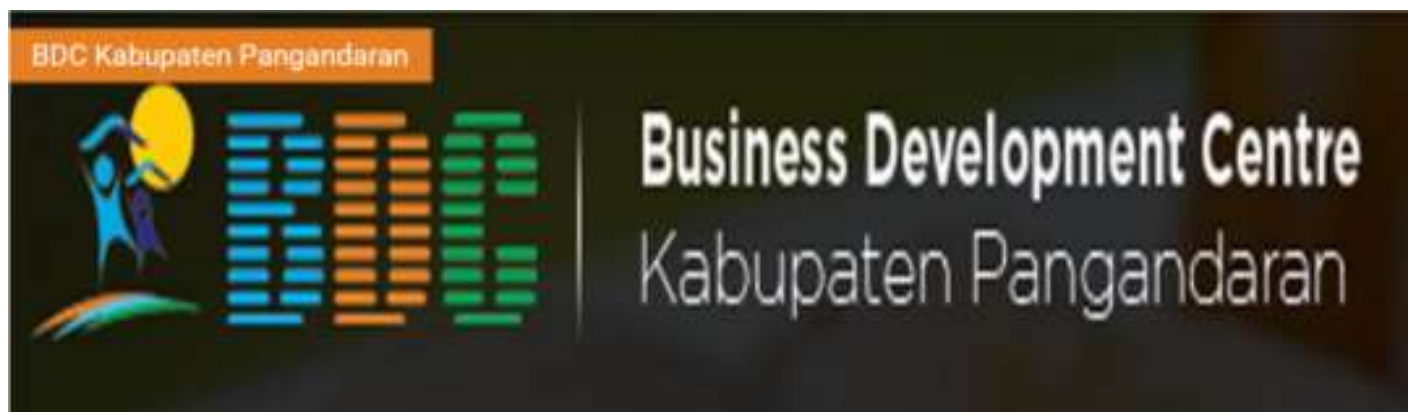

Gambar 3.2

Tampilan Web BDC

1) Jasa Pelatihan/Penyuluhan Tentang Produk, branding, pemasaran digital dan HAKI yang diharapkan peserta (gambar 3.1), selain dapat pengetahuannya juga dapat :

a. Menambah wawasan tentang bagaimana meningkatkan value produk dan memasukkan unsur kearifan budaya lokal sehingga menjadi produk unggulan yang memiliki daya saing

b. Membuat brand yang kuat diingat oleh pasar baik dalam bentuk, warna, gambar, makna dll yang menjadi identitas kuat para UKM

c. Menggunakan pemasaran digital secara efektif dan optimal melalui website yang telah kami bantu seperti gambar 3.2.

d. Mengajukan HAKI untuk produk yang mereka miliki, agar tidak terjadi pengakuan produk mereka oleh orang lain.

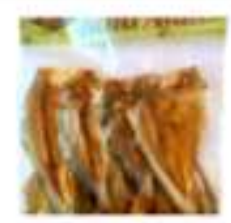

Kan Asin nulu Ayam

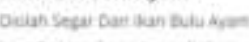

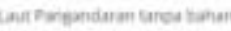
percuant

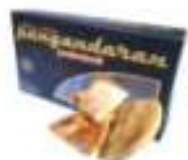

Ikan Asin Jamhal Roti

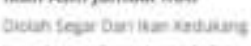

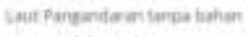
peryiunt diengan

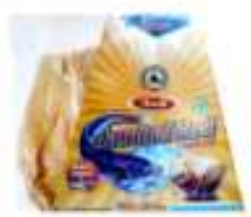

Ikan Asie Jambal Roti llesa: Duun Segar Dai ban Kefulars

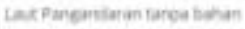
paryaiet onyan

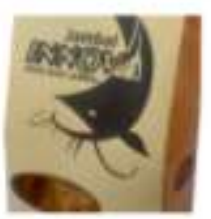

Abos ikan Jamba:

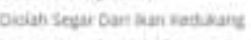
Gat Reryanderam Pahan Deren compuram aempian

Gambar 3.3 


\section{Produk UMKM}

2) Produk (Gambar3.3):

a. Resep Produk unggulan yang mengandung kearifan budaya lokal untuk para UKM

b. Logo / Brand untuk yang dapat mereka gunakan sebagai identitas dan menambah nilai tambah bagi para UKM

c. Website untuk para UKM memasarkan produknya.

3) Publikasi ilmiah di jurnal pengabdian

Upaya menyiapkan Pengelolaan BDC yang menghadirkan kontribusi signifikan dari pelaku usaha produktif melalui KSM (Kelompok Swadaya Masyarakat), kegiatan penguatan kapasitas atau pelatihan merupakan kegiatan yang sangat penting dan strategis dalam kegiatan Pilot BDC. Penguatan kapasitas ini dilakukan baik di level konsultan yang terdiri dari Tenaga Ahli OC dan Korkot (sebagai pendamping BDC) maupun di level BDC yang terdiri dari Komite dan Pengelola BDC. Business Development Center Kabupaten Pangandaran terdapat banyak produk hasil UMKM di Kabupaten Pangandaran yang dapat dikembangkan menjadi produk unggulan.

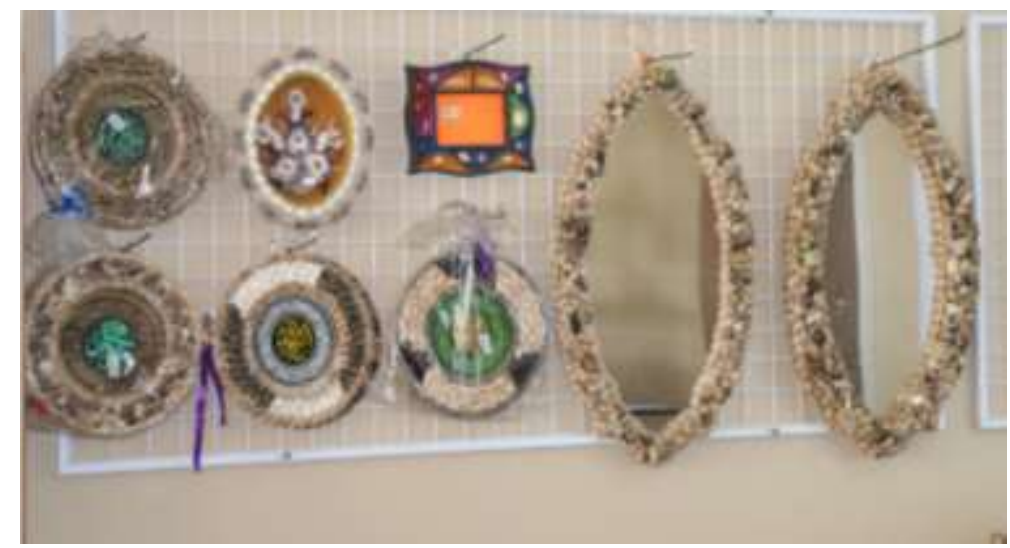

Gambar 3.4

Produk Unggulan 


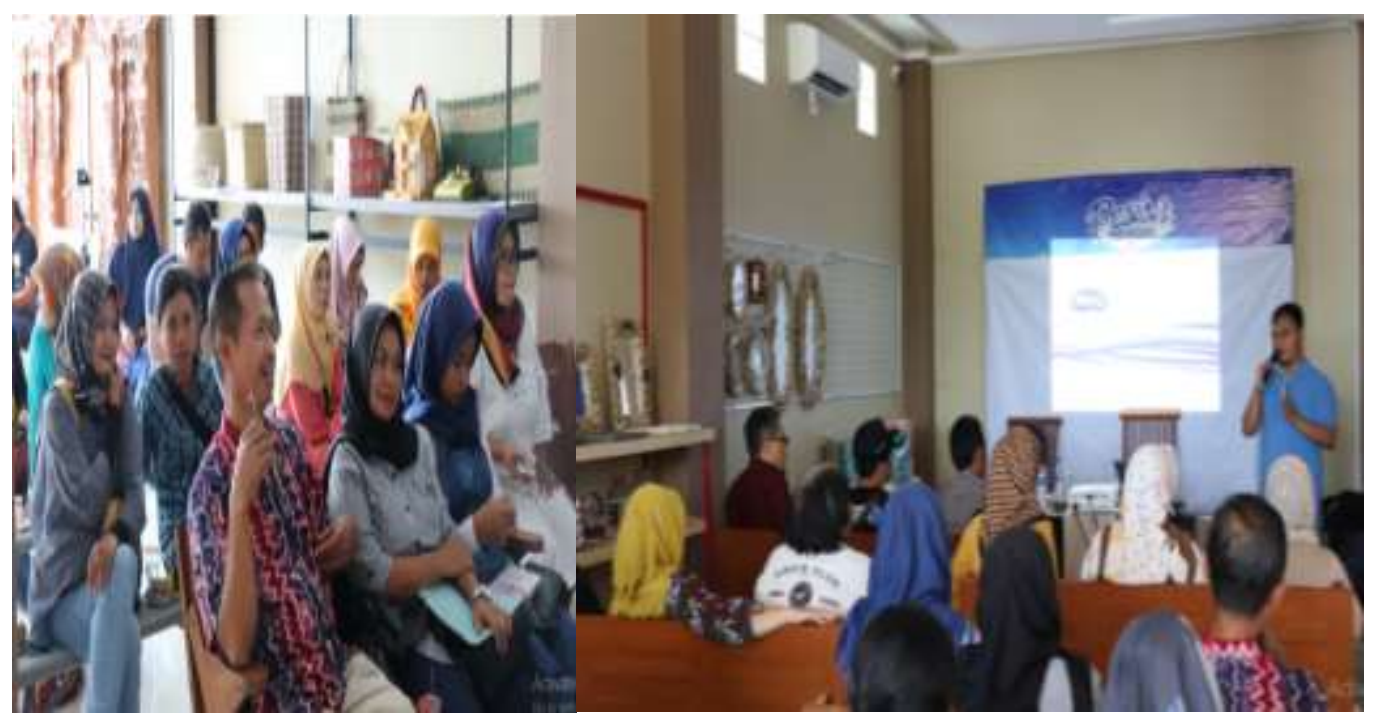

Gambar 3.5

Kegiatan Pemaparan materi tentang E-Commerce

Palmakita merupakan sebuah brand berbentuk usaha kecil menengah yang menjual gula kelapa kristal asli dan diproduksi dari Pangandaran. Palmakita diproses melalui cara tradisional oleh masyarakat lokal sehingga menciptakan kualitas organik. Gula kelapa kristal yang ditawarkan oleh Palmakita memiliki ukuran besar yaitu 200 gram dan ukuran kecil yaitu berbentuk sachet.

\section{DATA PRODUK}

Jenis produk $\quad$ : Gula kelapa kristal

Berat : $200 \mathrm{gr}$

Harga

Produksi

$$
\text { : Pangandaran }
$$

\section{DESKRIPSI LOGO DAN VISUAL}

Personality dari brand ini sendiri memiliki sifat yang organik, manis dan tradisional. Beberapa personality tersebut terlihat dari segi brand dan produk pada Palma kita yang memiliki gula kelapa kristal yang menghasilkan rasa manis berkualitas organik melalui proses tradisional. 


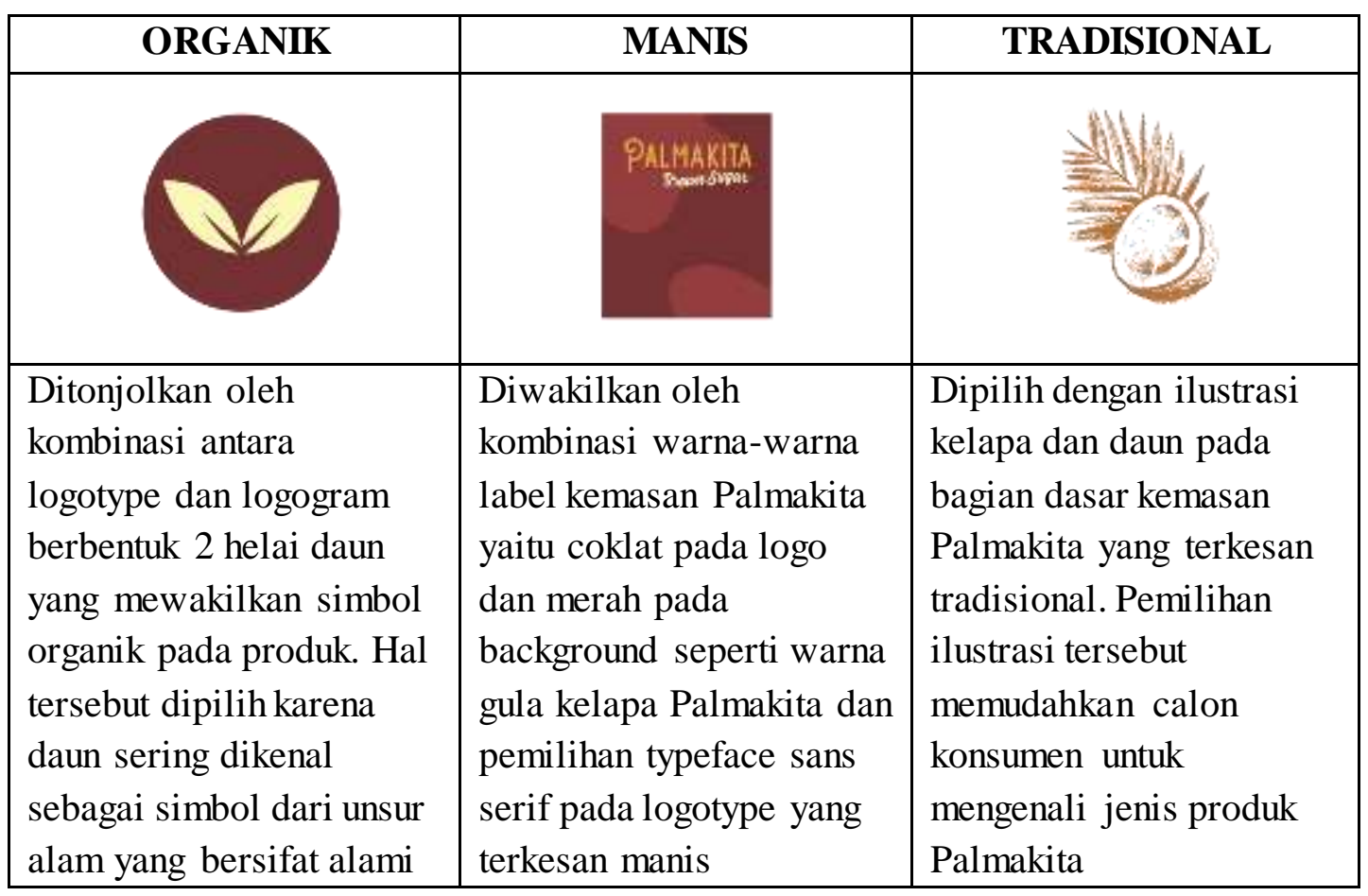

ELEMEN LOGO DAN VISUAL

\begin{tabular}{|l|l|}
\hline \multicolumn{2}{|l|}{ ELEMEN } \\
\hline OALMAHTA \\
\hline Logotype & \\
\hline
\end{tabular}




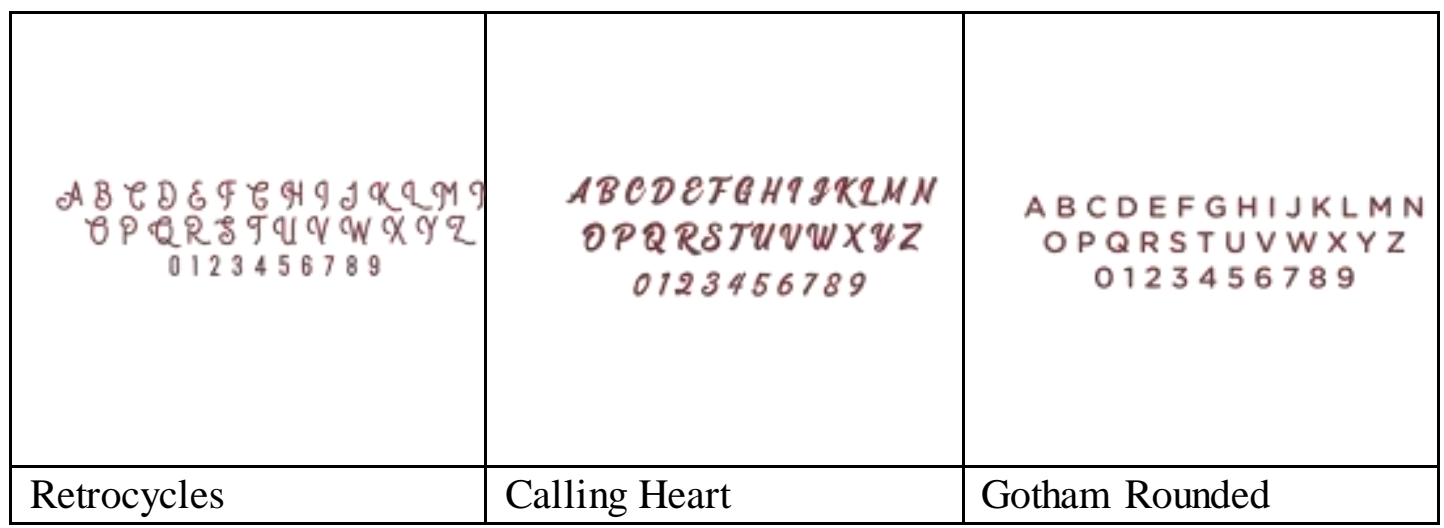

\begin{tabular}{|l|l|l|}
\hline \multicolumn{2}{|l|}{ WARNA } & \\
\hline & & \\
& & \\
\hline \#733132 & & \\
\hline
\end{tabular}

\section{FORMAT KEMASAN}

Kemasan ini menggunakan standing pouch berbahan kertas karton yang di sablon untuk bagian gambar atau ilustrasi pada dasar kemasan. Untuk membedakan varian produk tersebut adalah dengan menggunakan label berbahan kertas sticker yang praktis untuk di tempel. Penggunakan bahan dan teknis pada kemasan ini guna meminimalisir pengeluaran biaya untuk cetak kemasan dalam jumlah yang cukup banyak. Pada bagian bawah kemasan terdapat jendela/window transparan yang menampilkan isi produk gula kelapa dan kualitas produk kepada calon konsumen.

\section{INFORMASI KEMASAN}




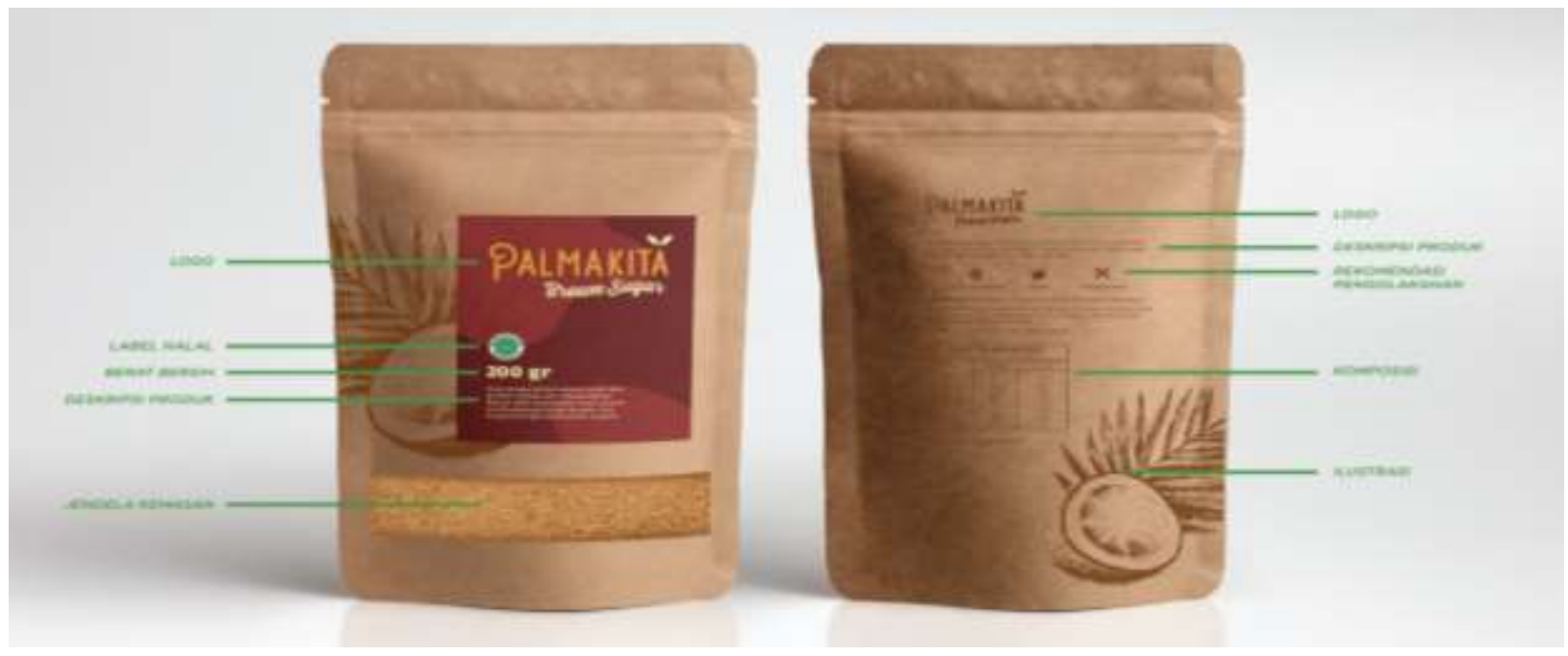

Gambar 3.6

Design Logo serta packaging yang telah dibuat oleh TIM

\section{PANDUAN KEMASAN}

Dengan menggunakan standing pouch berbahan kertas karton ini sangat mudah untuk diletakan dimanapun. Kemasan ini juga tidak mudah tumpah karena memiliki zip-lock atau kunci karet pada bagian atas sebagai buka -tutup kemasan.

\section{DAFTAR PUSTAKA}

[1] http://www.kadinpangandaran.or. id/berita/read/pemberdayaan-masyarakat/89/bdcpangandaran-hidupkan-perekonomian-di-pesisir-pangandaran.html

[2] https://news.mypangandaran.com/berita/read/bisnis/1893/gula-semut-varian-gulakhas-kabupaten-pangandaran

[3] Laporan Akhir Kebutuhan Inv Pangandaran Raya N.d. Scribd. https://id.scribd.com/document/381262647/Laporan-AkhirKebutuhan-Inv-Pangandaran-Raya, accessed June 20, 2019

[4] http://www.bdcpangandaran.com/profile/read/2/sambutan-ketua.html 
$\square$ Charity Jurnal Pengabdian Masyarakat Vol.02 No.01(2019) 